\title{
PENGARUH ORALIT WHO TERHADAP KADAR NATRIUM DAN KALIUM PLASMA PADA ANAK DIARE AKUT DENGAN DEHIDRASI
}

\author{
${ }^{1}$ Christin Jacobs \\ ${ }^{2}$ Jeanette Manoppo \\ ${ }^{2}$ Sarah Warouw
}

\author{
${ }^{1}$ Kandidat Skripsi Fakultas Kedokteran Universitas Sam Ratulangi Manado \\ ${ }^{2}$ Bagian Ilmu Kesehatan Anak Fakulkas Kedokteran Universitas Sam Ratulangi Manado \\ Email: christ_ephin@yahoo.com
}

\begin{abstract}
Acute diarrhea causes loss of large amounts of water and electrolytes especially sodium and potassium, which if not replaced can cause dehydration. In 2006, WHO recommended ORS with osmolarity $245 \mathrm{mmol} / \mathrm{l}$ as the administration of acute diarrhea with mild to moderate dehydration. The research objective is to determine the effect of WHO ORS to plasma sodium and potassium levels in children with acute diarrheal dehydration.Preexperimental study with pre-post test approach absence of a control group, was conducted from November, 2012 until January, 2013 at Pediatric section RSUP.Prof.DR.RD.Kandou Manado. Sample 20 patients acute diarrhea mild to moderate dehydration. Pasien blood samples were taken to measure sodium and potassium plasma level before and after treatment with WHO ORS $75 \mathrm{cc} / \mathrm{kg}$ for three hours. Results electrolyte levels when dehydration $60 \%$ isonatremia and $85 \%$ isokalemia Electrolyte level when rehydration $70 \%$ isonatremia and $70 \%$ isokalemia. Sodium mean levels when dehydration $136.1 \pm 5.2 \mathrm{mmol} / \mathrm{l}$ and when rehydration $136.1 \pm 3.45 \mathrm{mmol} / \mathrm{l}$ with $\mathrm{p}=0.5$. Potassium mean levels when dehydration $3.99 \pm 0.78 \mathrm{mmol} / \mathrm{l}$ and when rehydration $3.84 \pm 0.85 \mathrm{mmol} / \mathrm{l}$ with $\mathrm{p}=0.183$. Conclusions: Most electrolyte levels before and after rehydration isonatremia and isokalemia. There is no significant differences in plasma sodium and potassium levels before and after rehydration with WHO ORS.
\end{abstract}

Keywords Dehydration, Diarrhea, Potassium, Sodium, WHO ORS

\begin{abstract}
Abstrak: Diare akut menyebabkan hilangnya sejumlah besar air dan elektrolit terutama natrium dan kalium yang apabila tidak diganti dapat menyebabkan dehidrasi.Tahun 2006, WHO merekomendasikan oralit dengan osmolaritas $245 \mathrm{Mmol} / \mathrm{l}$ sebagai tata laksana diare akut dengan dehidrasi ringan sedang. Tujuan penelitian untuk mengetahui pengaruh oralit WHO terhadap kadar natrium dan kalium plasma pada anak diare akut dengan dehidrasi. Penelitian pra-eksperimental dengan pendekatan pre-post test tanpa adanya kelompok kontrol, berlangsung selama November 2012 sampai Januari 2013 di Bagian Ilmu Kesehatan Anak RSUP Prof.Dr.R.D.Kandou Manado. Sampel 20 pasien diare akut dehidrasi ringan sedang. Pasien diambil sampel darah untuk memeriksa kadar natrium dan kalium plasma sebelum dan sesudah terapi dengan oralit WHO $75 \mathrm{cc} / \mathrm{kgbb}$ selama tiga jam. Hasil didapatkan gambaran elektrolit saat dehidrasi terbanyak adalah isonatremia $60 \%$ dan isokalemia $85 \%$. Gambaran elektrolit saat rehidrasi terbanyak adalah isonatremia $70 \%$ dan isokalemia $70 \%$. Rerata kadar Natrium saat dehidrasi adalah $136,1 \pm 5,2 \mathrm{mmol} / \mathrm{L}$ dan saat rehidrasi adalah $136,1 \pm 3,45 \mathrm{mmol} / \mathrm{l}$ dengan $\mathrm{p}=0,5$. Rerata kadar Kalium saat dehidrasi adalah 3,99 $\pm 0,78 \mathrm{mmol} / \mathrm{l}$ dan saat rehidrasi adalah 3,84 $\pm 0,85 \mathrm{mmol} / \mathrm{l}$ dengan $\mathrm{p}=0,183$. Simpulan: Gambaran elektrolit sebelum dan sesudah rehidrasi terbanyak adalah isonatremia dan isokalemia.Tidak terdapat perbedaan bermakna kadar natrium dan kalium plasma sebelum dan sesudah rehidrasi dengan oralit WHO.
\end{abstract}

Kata kunci Dehidrasi,Diare,Kalium,Natrium,Oralit WHO 
Diare akut masih merupakan penyebab utama morbiditas dan mortalitas anak di negara berkembang dan merupakan salah satu penyebab kematian dan kesakitan tertinggi pada anak. Di dunia, sebanyak enam juta anak meninggal tiap tahunnya karena diare dan sebagian besar kejadian tersebut terjadi di negara berkembang. Hasil Riskesdas tahun 2007 diperoleh bahwa diare masih merupakan penyebab kematian bayi yang terbanyak yaitu $42 \% .{ }^{1}$ Profil kesehatan Provinsi Sulawesi Utara tahun 2008 memperlihatkan bahwa diare merupakan penyakit menular dengan jumlah terbanyak kedua yaitu sebesar 32.589. ${ }^{2}$

Diare menyebabkan hilangnya sejumlah besar air dan elektrolit (natrium, klorida, kalium, bikarbonat). Dehidrasi terjadi jika kehilangan air dan elektrolit tidak diganti. Menurut derajat dehidrasinya bisa tanpa dehidrasi, dehidrasi ringan, dehidrasi sedang atau dehidrasi berat. ${ }^{3,4}$ Penelitian tahun 2011 oleh Sulaiman ${ }^{4}$ menunjukkan bahwa derajat dehidrasi ringan-sedang akibat diare memiliki presentasi yang paling besar yaitu 62,5\% dibanding dehidrasi berat dan tanpa dehidrasi. Terapi rehidrasi oral dipercaya sebagai lini pertama untuk mengatasi diare dengan dehidrasi ringan-sedang. Tahun 2006 WHO dan UNICEF telah merekomendasikan oralit baru yaitu oralit dengan osmolaritas yang lebih rendah dari sebelumnya (245 Mmol/liter) yang efektivitasnya juga lebih baik daripada oralit formula lama.,

Oralit WHO diberikan sebagai intervensi terhadap gangguan keseimbangan konsentrasi natrium dan kalium. Hasil penelitian Yorva ${ }^{6}$ menyatakan bahwa oralit rekomendasi WHO ini tidak hanya mengembalikan keseimbangan konsentrasi natrium dan kalium, tetapi juga mempercepat penyembuhan diare dibanding dengan oralit lama sehingga penggunaannya dianjurkan pada penderita diare akut dengan dehidrasi ringan-sedang. Tetapi, dalam penelitian ini juga ditemukan kejadian ketidakseimbangan kadar natrium dan kalium dalam plasma setelah rehidrasi dengan oralit WHO tersebut. $^{6}$

\section{METODE}

Telah dilakukan penelitian pra-eksperimental dengan pendekatan pre-post test tanpa adanya kelompok kontrol untuk menilai apakah oralit WHO mempengaruhi kadar natrium dan kalium plasma pada anak diare akut dengan dehidrasi ringan sedang. Pasien dipilih secara konsekutif. Penelitian dilakukan di Bagian Ilmu Kesehatan Anak RSUP Prof.Dr.R.D. Kandou Manado. Kriteria inklusi pasien berusia satu bulan atau lebih yang menderita diare cair akut dengan dehidrasi ringan-sedang saat masuk rumah sakit dirawat di bagian anak RSUP Prof.R.D. Kandou Manado, lama diare sebelum dirawat kurang dari 14 hari dan mendapat persetujuan dari orangtua/wali penderita. Kriteria eksklusi, mempunyai kelainan kongenital pada saluran cerna, pasien gizi buruk (klinis dan antropmetri), menderita penyakit penyerta yang berat, anak dalam keadaan immunocompromised.

\section{HASIL}

Selama periode penelitian telah dirawat 110 anak dengan diare akut di bagian anak RSUP Prof.DR R.D Kandou Manado. Dari 110 kasus, yang merupakan diare akut dehidrasi ringan sedang sebesar 69 kasus dan yang memenuhi kriteria inklusi ialah sebesar 22 pasien. Namun, yang berhasil mengikuti penelitian sampai selesai hanya 20 pasien. Alasan kedua responden tersebut drop out dari penelitian ini ialah karena satu responden tidak melakukan pengambilan darah sesudah rehidrasi, satu responden dipasang cairan infus setelah informed consent.

Tabel 1. menunjukkan jenis kelamin laki-laki 13 pasien (65\%) dan yang berjenis kelamin perempuan sebanyak delapan pasien (35\%) dengan rerata usia sampel adalah 14 bulan. Tinggi badan rata-rata adalah $73 \mathrm{~cm}$ dan berat badan rata-rata adalah $8,07 \mathrm{~kg}$. Rerata indeks massa tubuh sampel penelitian ini sebesar $15,05 \mathrm{~kg} / \mathrm{m}^{2}$. Pada hasil pemeriksaan kimia darah sebelum dan sesudah rehidrasi didapatkan rerata kadar klorida plasma pada sampel 
Tabel 1. Karakteristik dasar pasien.

\begin{tabular}{llcccc}
\hline \multicolumn{1}{c}{ Variabel } & & N & Rerata & Min-Maks & SD \\
\hline Jenis Kelamin & Laki-laki & 13 & $65 \%$ & & \\
& Perempuan & 7 & $35 \%$ & & \\
Umur (bulan) & & 20 & 14 & $4-31$ & 6,6 \\
Tinggi badan (cm) & & 20 & 73 & $57-95$ & 9,7 \\
Berat badan (kg) & & 20 & 8,07 & $5-14,5$ & 2,33 \\
IMT (kg/m2) & & 20 & 15,05 & $12,44-17,82$ & 1,7 \\
Kadar Chlorida & Sebelum & 20 & 104 & $88,1-117$ & 6,28 \\
& Sesudah & 20 & 103,67 & $95,5-110$ & 4,42 \\
Status gizi & Baik & 18 & $90 \%$ & & \\
Keluhan penyerta & 2 & $10 \%$ & & \\
& Kurang & & & & \\
& Mantah & 13 & $65 \%$ & & \\
& Tidak & 7 & $35 \%$ & & \\
& Riwayat demam/ panas & & & & \\
& Ya & 9 & $45 \%$ & & \\
& Tidak & 11 & $55 \%$ & & \\
\end{tabular}

Tabel 2. Analisa Deskriptif Gambaran Natrium dan Kalium sebelum rehidrasi.

\begin{tabular}{lcll}
\hline Sebelum Rehidrasi & N & Rerata & \\
\hline Hiponatremia & 7 & $35 \%$ & \\
Isonatremia & 12 & $60 \%$ & \\
Hipernatremia & 1 & $5 \%$ & \\
& $\mathrm{n}=20$ & & $100 \%$ \\
\hline Hipokalemia & 2 & $10 \%$ & \\
Isokalemia & 17 & $85 \%$ & \\
Hiperkalemia & 1 & $5 \%$ & \\
& $\mathrm{n}=20$ & & $100 \%$ \\
\hline
\end{tabular}

Tabel 3. Analisa Deskriptif Gambaran Natrium dan Kalium sesudah rehidrasi.

\begin{tabular}{lcll}
\hline Sesudah Rehidrasi & N & Rerata & \\
\hline Hiponatremia & 6 & $30 \%$ & \\
Isonatremia & 14 & $70 \%$ & \\
& $\mathrm{n}=20$ & & $100 \%$ \\
\hline Hipokalemia & 5 & $25 \%$ & \\
Isokalemia & 14 & $70 \%$ & \\
Hiperkalemia & 1 & $5 \%$ & \\
& $\mathrm{n}=20$ & & $100 \%$ \\
\hline
\end{tabular}

Tabel 4. Analisa Kadar NaK sebelum dan sesudah rehidrasi dengan oralit WHO.

\begin{tabular}{lcccccc}
\hline \multicolumn{1}{c}{ Variabel } & \multicolumn{2}{c}{ Pre Rehidrasi } & \multicolumn{2}{c}{ Pasca Rehidrasi } & \multicolumn{2}{c}{ Analisa } \\
\hline & Rerata & SD & Rerata & SD & Hasil uji & P \\
Natrium & 136,1 & 5,2 & 136,1 & 3,45 & $\mathrm{t}=0,00$ & 0,5 \\
Kalium & 3,99 & 0,78 & 3,84 & 0,85 & $\mathrm{t}=0,92$ & 0,183 \\
\hline
\end{tabular}

Ket: $\mathrm{t}=$ Uji t berpasangan, menguji rata-rata variabel dua kali pengukuran.

Signifikansi p >0,05 (tidak terdapat perbedaan bermakna antara sebelum dan sesudah rehidrasi) 
Tabel 5. Perbedaan kadar Natrium dan Kalium sebelum dan sesudah rehidrasi.

\begin{tabular}{lcc}
\hline Variabel & Rerata & SD \\
\hline Perubahan Natrium(mmol/L) & 0.00 & 4.77 \\
Perubahan Kalium(mmol/L) & 0.14 & 0,76 \\
\hline
\end{tabular}

penelitian masih dalam rentang normal (isochloremia) yaitu sebesar $104 \mathrm{mmol} / \mathrm{l}$ dan 103,67 mmol/l. Status gizi pasien dengan gizi baik $90 \%$ dan gizi kurang $10 \%$.Keluhan penyerta yang dapat menjadi faktor perancu sehingga mempengaruhi kadar elektrolit pada sampel yaitu $60 \%$ pasien disertai dengan muntah dan 50\% pasien disertai dengan demam/riwayat panas.

Tabel 2. menunjukkan Saat dehidrasi, gambaran elektrolit pasien ialah 35\% hiponatremia, $60 \%$ isonatremia, $5 \%$ hipernatremia, 10\% hipokalemia, 85\% isokalemia, dan 5\% hiperkalemia. Sedangkan, pada Tabel 3. menunjukkan gambaran elektrolit pasien saat rehidrasi ialah 30\% hiponatremia, 70\% Isonatremia, $25 \%$ hipokalemia, 70\% Isokalemia, 5\% hiperkalemia. Terjadi pening- katan isonatremia (gambar 1) dan penurunan isokalemia (gambar 2). Namun, gambaran terbanyak pada pasien sebelum dan sesudah rehidrasi adalah isonatremia dan isokalemia.

Perbaikan hiponatremia saat rehidrasi hanya terjadi pada dua pasien, sedangkan satu pasien mengalami hiponatremia setelah rehidrasi. Terdapat satu kejadian hipernatremia sebelum rehidrasi, namun sesudah rehidrasi tidak lagi ditemukan (gambar 1).

Terjadi peningkatan kasus hipokalemia dari sebelum dan sesudah rehidrasi, sehingga kejadian isokalemia menurun saat rehidrasi. Terdapat kejadian hiperkalemia sebelum dan sesudah rehidrasi sebanyak satu pasien (gambar 2).

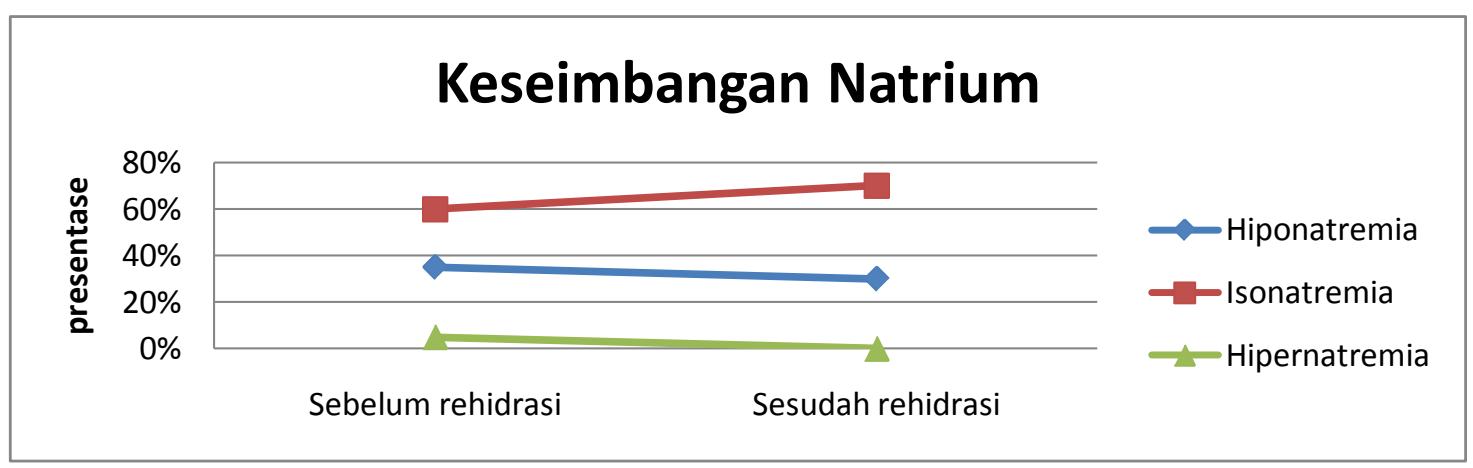

Gambar 1. Kejadian Hiponatremia, isonatremia, dan hipernatremia sebelum dan sesudah rehidrasi.

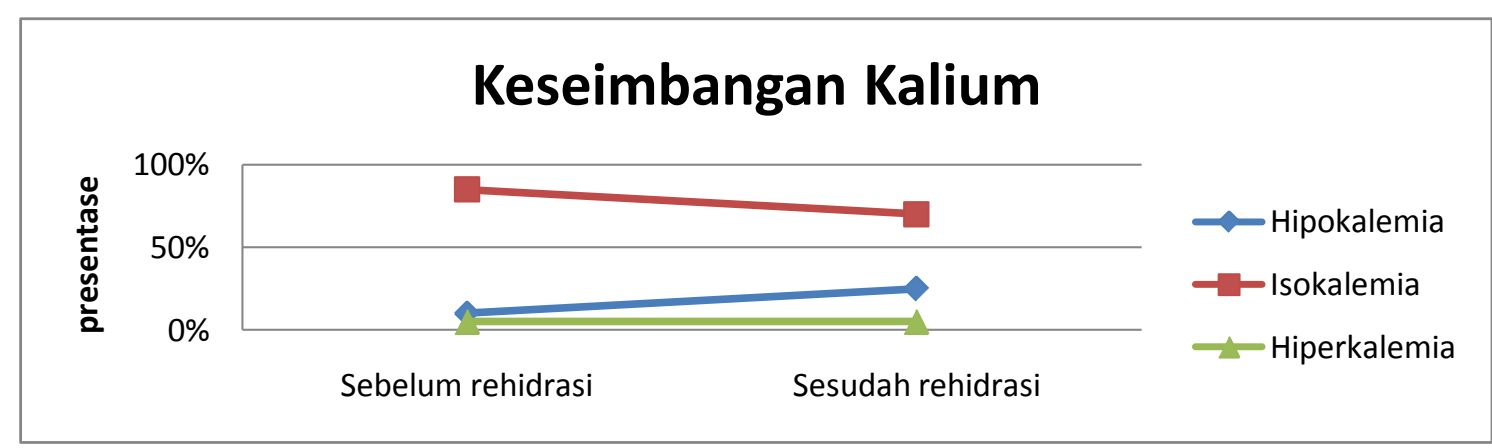

Gambar 2. Kejadian Hipokalemia, isokalemia, dan hiperkalemia sebelum dan sesudah rehidrasi. 
Tabel 4 menunjukkan kadar rerata natrium sebelum rehidrasi 136,1 $\pm 5,2$ $\mathrm{mmol} / \mathrm{l}$ dan kurang lebih enam jam setelah pasien keluar dari dehidrasi, kadar natrium rerata menjadi $136,1 \pm 3,45 \mathrm{mmol} / \mathrm{l}$. Tabel 5 menunjukkan,terdapat perbedaan sebesar $0.00 \pm 4.77 \mathrm{mmol} / \mathrm{l}$. Secara klinis dan secara statistik menunjukkan tidak terdapat perbedaan yang bermakna.

Kadar rerata kalium sebelum dilakukan rehidrasi 3,99 $\pm 0,78 \mathrm{mmol} / \mathrm{l}$ dan \pm 6 jam setelah pasien keluar dari dehidrasi kadar rerata kalium menjadi 3,84 $\pm 0,85$ $\mathrm{mmol} / \mathrm{l}$. Menunjukan suatu perbedan yang tidak bermakna antara sebelum dan sesudah rehidrasi dengan $\mathrm{p}=0,183$ seperti tertera pada tabel 4. Perbedaannya sebesar 0,14 $\pm 0,76 \mathrm{mmol} / \mathrm{l}$ (tabel 5).

\section{DISKUSI}

Dari hasil analisa deskripstif didapatkan bahwa dehidrasi yang paling banyak terjadi pada sampel penelitian ini ialah dehidrasi isotonik dimana kehilangan air diikuti dengan kehilangan elektrolit dalam jumlah yang sama. Isonatremia dan isokalemia merupakan gambaran terbanyak sebelum dan sesudah rehidrasi dengan oralit WHO. Namun, masih terdapat keja-dian hiponatremia yaitu sebanyak 30\%, kejadian hipokalemia sebesar 25\% dan kejadian hiperkalemia yaitu 5\%. Hal in didukung juga oleh penelitian yang dilakukan oleh Yorva $^{6}$ masih terdapat kejadian hiponatremia $12,5 \%$ dan hipernatremia $4,2 \%$ setelah rehidrasi dengan oralit.

Pada penelitian ini tidak mendukung hipotesis adanya perbedaan kadar natrium plasma sebelum dan sesudah intervensi dengan oralit WHO pada anak diare akut dengan dehidrasi. Tidak terjadi perubahan kadar rerata natrium dalam cairan ekstravaskuler setelah perlakuan baik dinilai secara klinis dan statistik.

Dalam penelitian ini, kadar Natrium saat dehidrasi $136,1 \pm 5,2 \mathrm{mmol} / \mathrm{l}$ dan saat rehidrasi $136,1 \pm 3,45 \mathrm{mmo} / \mathrm{l}$ dengan $\mathrm{p}=$ 0,5 . Rentang waktu pengambilan sampel darah dilakukan minimal enam jam sesudah penderita tidak menunjukkan tanda-tanda dehidrasi. Hasil yang sama juga didapatkan dari penelitian Samar, $\mathrm{dkk}^{7}$ dengan jarak pengambilan enam jam setelah menggunakan ORS pada anak diare akut tanpa atau dengan dehidrasi, kadar natrium rerata sebelum rehidrasi yaitu $133 \pm 3.4 \mathrm{mmol} / \mathrm{L}$ dan sesudah rehidrasi $133 \pm 2.9 \mathrm{mmol} / \mathrm{L}$ dengan $\mathrm{p}=0,173$ yang menyatakan bahwa tidak ada perubahan bermakna. Hasil yang berbeda didapatkan dari penelitian yang dilakukan Alam, dkk ${ }^{8}$. Kadar Na sebelum rehidrasi dengan oral melalui NGT adalah sebesar $141 \mathrm{mmol} / \mathrm{L}$. Sesudah rehidrasi selama tiga jam, diambil sampel darah dan terlihat penurunan kadar Natrium rerata menjadi $139 \mathrm{mmol} / \mathrm{L}$. Pengambilan sampel darah dalam 24 jam juga tidak memperlihatkan suatu perubahan yang berarti secara klinis. Hal ini ditunjukkan pada penelitian Khan, $\mathrm{dkk}^{9}$ yang memeriksa serum Natrium pada pasien diare akut dengan atau tanpa dehidrasi, menunjukkan kadar Na sebelum rehidrasi adalah $137 \pm 4$ $\mathrm{mmol} / \mathrm{l}$ menjadi $137 \pm 3 \mathrm{mmol} / \mathrm{l}$ sesudah rehidrasi. Didukung juga oleh penelitian yang dilakukan $C H O I C E^{10}$ serum Natrium rerata saat masuk rumah sakit $137 \pm 7$ $\mathrm{mmol} / \mathrm{l}$. Setelah mengonsumsi oralit dengan osmolaritas $245 \mathrm{mmol} / \mathrm{L}$ terjadi penurunan rerata natrium sebesar $1 \mathrm{mmol} / \mathrm{l}$ menjadi $136 \pm 0.4 \mathrm{mmol} / \mathrm{l}$ dalam 24 jam.

Sistem keseimbangan air dan elektrolit dipertahankan melalui integrasi dan fungsi ginjal, hormonal, dan saraf yang memerlukan waktu 4-6 jam. Selama pasien mengalami diare, berarti terjadi gangguan proses absorpsi dan sekresi cairan serta elektrolit di dalam saluran cerna. Timbulnya penurunan absorbsi dan peningkatan sekresi mengakibatkan cairan berlebihan melebihi kapasitas kolon dalam mengabsorpsi. Gangguan pada sistem pencernaan dapat berupa kerusakan pada ion transport, salah satunya $\mathrm{Na}^{+} / \mathrm{H}^{+}$yang juga menimbulkan gangguan absorpsi. Pada kejadian diare akut dengan dehidrasi ringan sedang, cairan yang hilang digantikan dalam beberapa tahapan. Setelah tanda-tanda dehidrasi dari anak tersebut sudah tidak ada, atau setelah anak dinyatakan dalam kondisi diare akut tanpa dehidrasi, masih dibutuhkan cairan 
sebesar 50-100 cc/kgbb untuk mempertahankan dan mengganti cairan yang hilang selama anak masih mengalami diare. ${ }^{3,11,12}$

Hal tersebut didukung dari hasil penelitian yang dilakukan oleh Thermiany, $\mathrm{dkk}^{13}$ kadar Natrium dinilai saat masuk rumah sakit dan saat pasien dinyatakan sembuh dari diare, terdapat rerata kadar Natrium dehidrasi $135.0 \mathrm{mmol} / \mathrm{L}$, meningkat saat rehidrasi $136.7 \mathrm{mmol} / \mathrm{l}$, terdapat perubahan rerata natrium sebesar 1,7 mmol/L. Begitu juga yang didapatkan dari penelitian Dutta, $\mathrm{dkk}^{14}$ dengan menggunakan larutan yang mengandung Natrium 60 $\mathrm{mmol} / \mathrm{l}$, kadar rerata Natrium saat masuk ke rumah sakit adalah $130 \pm 3.3 \mathrm{mmol} / \mathrm{l}$, setelah pasien sembuh dari diare menjadi 134.4 $\pm 3.1 \mathrm{mmol} / \mathrm{l}$, terdapat kenaikan sebesar 4,4 $\mathrm{mmol} / \mathrm{l}$.

Konsentrasi kalium dalam cairan ekstravaskuler sebelum dan sesudah perlakuan menunjukkan penurunan secara klinis, tetapi secara statistik tidak bermakna. Kadar Kalium rerata saat masuk rumah sakit sebesar 3,98 mmol/l, kurang lebih enam jam setelah terehidrasi kadar kalium menjadi 3,84 $\mathrm{mmol} / \mathrm{l}$, terjadi penurunan sebesar $0,14 \mathrm{mmol} / \mathrm{l}$ dengan $\mathrm{p}>0,05$. Temuan ini bertentangan dengan hasil penelitian Alam, $\mathrm{dkk}^{8}$ dengan menggunakan oralit melalui NGT terjadi peningkatan dari 4.6 $\pm 0.09 \mathrm{mmol} / \mathrm{l}$ sesudah rehidrasi selama tiga jam menjadi $4.7 \pm 0.10 \mathrm{mmol} / \mathrm{l}$. Begitu pula penelitian yang dilakukan oleh Hasri, dkk ${ }^{11}$ pada pasien diare akut dengan dehidrasi ringan sedang maupun berat, menunjukkan peningkatan kadar Kalium sebelum dan sesudah rehidrasi menggunakan cairan intravena KAEN 3B yang mengandung kadar Kalium sebesar 20 mmol/l.

Hasil yang sama dengan penelitian ini didapatkan juga oleh Ahmed, dkk ${ }^{15}$ pemberian oralit pada penderita diare akut dehidrasi ringan-sedang di Bangladesh yang mengandung kalium $20 \mathrm{mmol} / \mathrm{l}$ menyebabkan penurunan Kalium plasma pada 24 jam setelah dirawat dan masih tetap turun setelah 48 jam, walaupun pemberian oralit tetap dilanjutkan. Kehilangan kalium dapat terjadi selama masih terjadi diare. Hal tersebut dapat terjadi karena integrasi dan fungsi ginjal, hormonal, saraf memerlukan waktu dalam mempertahankan volume dan osmolaritas CES. ${ }^{11}$

Kelemahan penelitian ini ialah tidak dilakukan pengukuran elektrolit yang keluar baik melalui urin dan feses dan sampel penelitian tidak dibedakan berdasarkan status gizi (masih terdapat status gizi kurang dalam penelitian ini).

\section{SIMPULAN}

Gambaran natrium sebelum dan sesudah rehidrasi terbanyak adalah isonatremia. Gambaran kalium sebelum dan sesudah rehidrasi terbanyak adalah isokalemia. Secara klinis dan statistik tidak terdapat perbedaan antara kadar natrium sebelum dan sesudah. Secara klinis terjadi penurunan kadar kalium, tetapi secara statistik perbedaan kadar kalium sebelum dan sesudah rehidrasi tidak berbeda bermakna.

\section{UCAPAN TERIMA KASIH}

Ucapan terima kasih diberikan kepada: dr. Hj. Nurhayati Masloman, SpA(K) selaku dosen penguji satu yang telah memberikan arahan dan masukan dan kepada Prof. Dr. dr. Adrian Umboh, SpA(K) selaku dosen penguji dua yang telah memberikan masukan yang sangat berguna bagi penulis. Dan kepada semua pihak yang sudah membantu secara langsung maupun tidak langsung yang namanya tidak dapat di sebutkan satu persatu atas ilmu yang berguna bagi penulis.

\section{DAFTAR PUSTAKA}

1. Badan Penelitian Dan Pengembangan Departemen Kesehatan RI. Lapran Hasil Riset Kesehatan Dasar Nasional 2007.Jakarta: RISKESDAS;2008.1-280.

2. Dinas Kesehatan Provinsi Sulawesi Utara. Profil kesehatan Sulawesi Utara tahun 2008. Manado. 2009.

3. Subagyo B, Santoso NB. Diare akut. In: Juffrie M, Soenarto SSY, Oswari H, Arief S, Rosalina I, Mulyani NS, penyunting. Gastroenterologi-Hepatologi. Edisi 3. 
Jakarta: Badan penerbit IDAI; 2012.p.87116.

4. Yusuf S. Profil diare di Ruang Rawat Inap Anak. Sari Pediatri. 2011;13: 265-70.

5. World Gastroenterology Organisation Practice Guideline. Acute diarrhea. March 2008.

6. Sayoeti YSR. Cairan Rehidrasi Oral Osmolaritas Rendah Dibandingkan Oralit untuk Pengobatan Diare Akut pada Anak. Sari Pediatri. 2008;9:304-8.

7. Ijaz SF, Afzal MF, Iqbal SMJ, Sultan MA, F Asrihani. Comparison of serum sodium before and after use of reduced osmolarity ORS solution in children with acute watery diarrhea. JSZMC;2:224-6

8. Nager AL, Vincent wang. Comparison of nasogastric and intravenous methods of rehydration in pediatric patients with acute dehydration. Pediatrics. 2002;109:566-72

9. Khan AM, Sarker SA, Alam NH, Hossain MS, Fuchs GJ, Salam MA. Low Osmolar Oral Rehydration Salts Solution in the Treatment of Acute Watery Diarrhoea in Neonates and Young Infants: A Randomized, controlled Clinical Trial. J Health Popul Nutr. 2005;23:52-7.

10. CHOICE Study group. Multicenter, Randomized, Double-Blind Clinical Trial to Evaluate the Efficacy and Safety of a Reduced Osmolarity Oral Rehydration Salts Solution in Children With Acute Watery Diarrhea. Pediatrics.
2001;107:613-8.

11. Salwan H, Firmansyah A, Boediarso A, Hegar B, Kadim M, Alatas FS. Gambaran kadar natrium dan kalium plasma berdasarkan status nutrisi sebelum dan sesudah rehidrasi pada kasus diare yang dirawat di departemen IKA RSCM. Sari Pediatri. 2008;9:406-11.

12. Meyers RS. Pediatric Fluid and electrolyte therapy. J Pediatr Pharmacol Ther. 2009;14:204-11

13. Sundari TA, Soetjininsih, Soenarto SSY, Karyana IPG. Efficacy of reduced osmolarity oral rehydration solution, ricebased oral rehydration solution, and stndard WHO oral rehy-dration solution in children with acute diarrhea - a randomized open trial. Pediatr Indones. 2009;49:169-76.

14. Dutta P,Mitra U, Manna B, Niyogi S K, Roy K, Mondal C, Bhattacharya S K. Double blind, randomised controlled clinical trial of hypo-osmolar oral rehydration salt solution in dehydrating acute diarrhoea in severly malnourished (marasmic) children. Arch Dis Child. 2001;84: 237-40.

15. Ahmed ASM, Islam MR, Kabir I. Efficacy of oral rehydration in correcting serum potassium deficit of children with acute diarrhea in Bangladesh. J Trop Pediatr. 1988;34: 24-7. 